\title{
education policy
} analysis archives

A peer-reviewed, independent, open access, multilingual journal

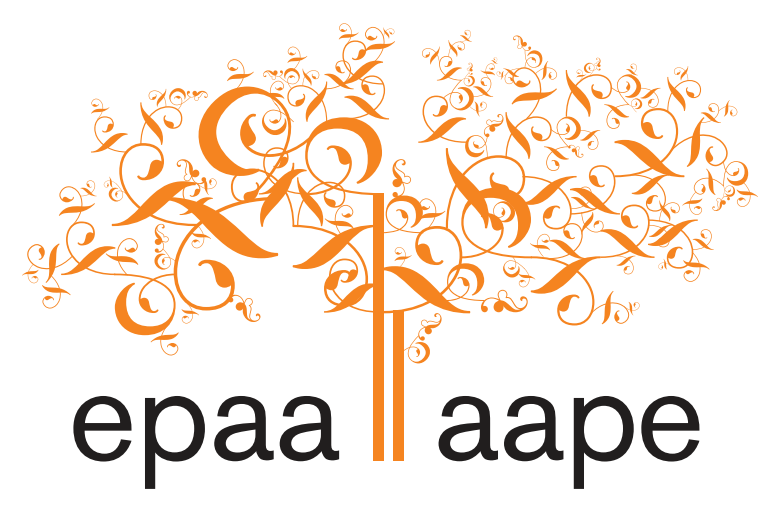

Arizona State University

\section{Can school structures improve teacher-student relationships? The relationship between advisory programs, personalization and students' academic achievement}

\author{
Larry McClure, Susan Yonezawa and Makeba Jones \\ University of California, San Diego
}

Citation: McClure, L., Yonezawa, S., \& Jones, M. (2010). Can school structures improve teacher student relationships? The relationship between advisory programs, personalization and students' academic achievement. Education Policy Analysis Archives, Vol 18 (17). Retrieved [date], from http://epaa.asu.edu/ojs/article/view/719

\begin{abstract}
This study focused on the relationships between student-perceived levels of personalization, students' opinions about advisory period, and academic outcomes. Surveys were administered to 10,044 students over three consecutive years at 14 redesigned small schools and survey responses were linked to students' weighted single-year grade point averages and English Language Arts standardized test scores. Results of a series of multi-level models indicated that more positive perceptions of personalization were predictive of better academic outcomes. Student perceptions of the advisory period were related to academic achievement as well, but in the opposite direction: more positive feelings about advisory period were associated with worse academic outcomes. These results are consistent with qualitative work suggesting that higher levels of personalization are associated with higher levels of academic achievement, improved school culture, and more student engagement. However, these results also suggest that the relationships among advisory period, personalization and academic outcomes are not as straightforward as was previously thought.
\end{abstract}

Keywords: personalization; advisory; academic achievement; school structures 


\begin{abstract}
¿Pueden las estructuras escolares mejorar las relaciones entre estudiantes y docentes? La relación entre los programas de asesoramiento, personalización y el logro académico de los estudiantes

Resumen: Este estudio se centró en las relaciones entre las percepciones de estudiantes sobre niveles de personalización, sus opiniones sobre los periodos de asesoramiento, y los resultados académicos. Durante tres años consecutivos se administraron 10.044 encuestas a estudiantes en 14 escuelas pequeñas y re-estructuradas. Las respuestas fueron vinculadas a los promedios generales de las notas de los estudiantes ponderadas durante un solo año y a los resultados de las pruebas normalizadas en Artes del Lenguaje Inglés. Los resultados de una serie de modelos de niveles múltiples indicaron que las percepciones más positivas sobre la personalización pronosticaron mejores resultados académicos. Las percepciones de los estudiantes sobre el período de asesoramiento también fueron relacionados con el logro académico, pero en dirección opuesta: sentimientos positivos acerca de los períodos de asesoramiento se asociaron con peores resultados académicos. Estos resultados son consistentes con un trabajo cualitativo que sugiere que niveles más altos de personalización son asociados con niveles más altos de logros académicos, mejorías en la cultura escolar y más compromiso de los estudiantes. Sin embargo, estos resultados también sugieren que las relaciones entre períodos de asesoramiento, personalización y resultados académicos no son tan sencillas como se había pensado anteriormente.
\end{abstract}

Palabras claves: personalización; asesoramiento; rendimiento académico; estructuras escolares.

\title{
¿Podem as estruturas escolares melhorar as relações entre alunos e professores? A relação entre os períodos de orientação, atenção individualizada e o desempenho acadêmico dos estudantes
}

Resumo: Este estudo focalizou as relações entre as percepções dos alunos sobre os níveis de atenção individualizada e suas opiniões sobre os períodos de orientação, com resultados acadêmicos. Por três anos consecutivos foram administrados 10.044 questionários a alunos em 14 pequenas escolas que passaram for reformas. As respostas foram relacionadas com as médias globais das notas dos alunos durante um único ano ponderado e os resultados de testes padronizados na disciplina Língua Inglesa. Os resultados de uma série de modelos multi-nível indicaram que as percepções mais positivas sobre a atenção individualizada prognosticaram melhores resultados acadêmicos. As percepções dos alunos sobre o período de orientação também foram relacionadas com os resultados acadêmicos, mas na direção oposta: sentimentos positivos sobre os períodos de orientação foram associados com piores resultados acadêmicos. Estes resultados coincidem com um trabalho qualitativo que sugere que níveis mais elevados de atenção individualizada estão associados com níveis mais elevados de rendimento acadêmico, melhorias na cultura escolar e mais engajamento dos alunos. No entanto, esses resultados também sugerem que as relações entre períodos de orientação, atenção individualizada e os resultados acadêmicos não são tão simples quanto se pensava anteriormente.

Palavras-chave: atenção individualizada; orientação; desempenho acadêmico; estruturas escolares.

\section{Introduction}

One of the most important efforts on the part of school reformers over the past two decades has been the effort to make secondary schools "places of human scale" (Sizer, 1984). These efforts stem in part from the belief that the contexts in which students learn are critical factors in motivating and educating students (Steinberg \& Allen, 2002). Contextual factors that have captured educators and policymakers' attention recently include reducing the size of schools and classrooms 
and facets of classroom instruction to increase engagement and the rigor of pedagogy and curricula. But significant efforts have also been made to "personalize" schools by improving the relationships and overall feelings of connectedness among students, teachers, and the curriculum at hand (Klem \& Connell, 2004; Steinberg \& Allen, 2002).

In this paper, we present findings from a three-year study of students' perceptions of personalization and, specifically, advisory as a reform strategy and its relationship to students' academic progress at 14 recently converted small high schools in a large, urban school district in California. This study examined the degree to which students' sense of personalization (connections to the school and to adults at the school) interacted with students' academic achievement, as measured by standardized test scores and weighted grade-point averages (WGPAs). In particular, we examined the relationship between students' perceptions of formal structures to enhance personalization, exemplified by the advisory period, and students' academic achievement.

\section{Relationships: A focus on "personalization"}

A key component of improving schooling environments has been improving personalization, that is, tightening connections between students and their learning environments (e.g. teachers, other adults, student peers, curriculum, overall school culture). Personalization matters because young people who are engaged emotionally, cognitively and behaviorally in their education are less likely to show signs of alienation and more likely to be connected to school (Fredricks, Blumenfield, \& Paris, 2004; Hallinan, 2008). Students who feel connected to their school are more likely to exhibit healthy lifestyle behaviors (McNeely \& Falci, 2004; McNeely, Nonnemaker \& Blum, 2002). Increased school connectedness is also related to educational motivation, classroom engagement and better attendance; all of which are linked to higher academic achievement (Blum \& Libbey, 2004; Blum, McNeely, \& Rinehart, 2002).

The importance of personalization in today's educational reform landscape is underscored by the time and money focused on reducing school and class size. These efforts have been supported by research that has shown increased academic achievement of students, particularly lowincome and minority students, when student-to-teacher ratios and school populations are reduced (Lee, Bryk \& Smith, 1993a; 1993b; Lee \& Smith, 1993, 1995, 1996, 1997; Lee, Smith \& Croninger, 1997; Mosteller, 1995; Mosteller, Sachs \& Light, 1996).

In particular, the idea behind smaller schools has been that small schools can produce what Bryk and Driscoll (1988) call a more "communal school organization" and that small school can become "tighter-knit," providing higher levels of social support to students. More positive, personalized school cultures result in more caring relationships among teachers and students and results in fewer students "getting lost." As schools shrink in size, teachers are presumed better able to discuss students' progress and to compare information. Advisories, adult-student mentoring programs, and enhanced adult-led extra curricular programs are a few ways small and large schools try to enhance adult-student relationships.

Because of the evidence supporting the benefits of reducing the scale of schools and classrooms, the Bill and Melinda Gates and Carnegie Foundations have invested hundreds of millions of dollars to assist large urban school districts in reducing the size of their comprehensive high schools. Some critics contend, however, that when the cost of these conversions is calculated on a "per graduate" as opposed to a "per student" basis, some evidence exists that the resulting conversions are more costly than comprehensive high schools (Stiefel, Berne, Iatarola \& Fruchter, 2000).

The importance of personalization

There is growing evidence that indicates greater personalization -- improved, trusting relationships particularly among teachers and students -- are able to raise students' expectations for 
themselves and teachers' expectations for students. But we are still unsure how increasing personalization helps raise academic achievement on various measures (e.g. state examinations, weighted grade-point averages, on-track for college entrance).

This paper investigates the extent to which student perceptions of personalization and advisory are related to students' academic achievement. In the sections that follow, we provide a brief history of the small high school conversions in one large urban school district in California where the research was conducted, as well as a breakdown of methods used, results, and a discussion of the implications of this and future work.

\section{A Brief History of Small High Schools in Avalon Unified School District}

Avalon (a pseudonym) is one of the largest districts in California with over 221 schools. Although struggling with declining enrollment, like most California districts, it serves over 130,000 K-12 students. More than half are eligible for free and reduced lunch (56.9\%). Nearly 40,000 students (29.5\% of students) in Avalon are designated English Learners and together speak 64 different languages, although the predominant language is Spanish. The district is heavily Latino (44.4\%) with white students (25.3\%) making up the second largest group, and Asian-Pacific Islanders (17\%) and African American students (13.5\%) constituting the remainder.

With over 29 high schools in its domain, Avalon Unified has struggled over the decades to ensure that all the students it enrolls have adequate access to a personalized and rigorous education. Because large comprehensive high schools tend to be impersonal, Avalon high schools have also been easy places for students to remain anonymous and "get by." High schools in Avalon have failed to produce graduates with technical skills and knowledge transferable to the post-secondary world. About $40 \%$ of Avalon's graduating seniors meet minimum entrance requirements for the University of California and California State University systems, and of Avalon graduates enrolled in these institutions, 50\% required remedial work in English and/or mathematics.

In 2004, Avalon set out to renew three of its poorest performing comprehensive high schools. A key facet of the district's high school reform strategy to go from "large to small" was to make its schools more personal and challenging for students. Administrators and teacher leaders believed more personalized learning environments could increase students' willingness to engage in challenging coursework and, thereby, increase their capacity to learn complex material. Each of the three comprehensive high schools had previously served about 2,000 students; the 14 new small high schools served approximately 400 students each, although class sizes were not significantly reduced. The new small schools were autonomous small schools occupying the same physical space as the previous comprehensive high schools. The idea was that the smaller and hopefully tighter-knit teaching faculty at each school would come to know well the 400 students they served. In preparation for the changes, the district administration published this definition of personalization within their high school reform efforts: "Personalization involves the development of a school climate and organization that produces strong, personal support for each student and a feeling on the part of the student that the adults in the schools believe that the student can and will succeed." (Avalon Unified, public communication on website, March 12, 2002). Research on the Effectiveness of Advisory Programs

Advisory programs began in the mid-1980s when they emerged as a part of the early middle school reform movement (Alexander \& Williams, 1965) which attempted to re-make junior high schools into a more successful transitional educational experience for students. Established in part from research showing that early adolescents in particular face unusual social and emotional stresses and would benefit from closer child-adult relationships, 
advisory programs, for the past two decades, have ranged from being seen as essential to being viewed as a waste of time and resources.

The structures of advisory are well known; the concept and practice of gathering students and an educator together for brief, regular periods in a non-content specific setting to deal with cognitive and affective educational topics. It has long been known under a variety of titles: homeroom, home base, teacher-counselor programs, mentoring, and teacher-based guidance (Epstein \& MacIver, 1990). The primary goal of advisory programs is usually to create tighter relationships between adults and students to foster a more supportive school climate overall.

While the various structures and intent of the advisory period is well known, little research exists supporting the social-emotional and cognitive benefits of advisory programs. The most comprehensive research review, now more than a decade old, was conducted by Galassi, Gulledge and Cox (1997) who examined the state of research on advisory and found few studies methodologically sound enough to evaluate advisory effectiveness. They found that the primary problems were 1) outcome measures often consisted of value impressions data; 2) few studies included pre-tests or control groups; and 3) meta-level variables of school climate and/or standardized academic outcomes measures were rarely used. Since 1997, there have been no additional comprehensive and rigorous studies conducted on advisory programs' effectiveness (Makkonen, 2004). Most of the published work has focused instead on how to implement advisory programs, train staff, and provide appropriate administrative support (Gewertz, 2007). Yet, despite the lack of research on advisory effects, widespread implementation of advisory programs continues.

Within the small school reforms in Avalon Unified, advisory was seen as a key component of the move to greater personalization. Each of the 14 small schools had a formal advisory program, which operated similar to an additional period several times a week, wherein a core group of students met regularly with their advisor. Although the programs varied somewhat in the amount of time they devoted to advisory per week or the way teachers were assigned to students, all 14 schools began their advisory in 2005, all maintained them through 2009, and all used a combination of structured and unstructured activities/time in their advisory programming.

\section{Method}

\section{Participants}

In the spring of 2005, 2006, and 2007, students attending 14 small schools in Avalon Unified completed a survey about their academic experiences and perceptions of adult support in the newly formed small schools. The survey item construction was based on the literature relating to small school conversions (School Redesign Network, 2000). Students at all grade levels (with the exception of $12^{\text {th }}$ graders in 2005) completed the annual spring survey during a two-week administration window. Responses were scored using Teleform ${ }^{\circledR}$ software and matched to districtprovided academic and demographic databases using student-provided identification numbers on the survey cover sheet.

Overall survey response rates for 2005, 2006 and 2007 were $66.9 \%, 62.3 \%$, and $80.0 \%$ and match rates to the academic files were $95.1 \%, 94.4 \%$ and $88.9 \%$, respectively. Table 1 provides demographic information for the respondents. There were similar numbers of males and females and the proportion of students responding at each grade level was roughly equivalent across the three survey years. In addition, the Race/Ethnicity of respondents was diverse and reflected the composition of the schools: 18\% African American, 55\% Hispanic, 12\% White and the remaining 
$15 \%$ divided among members of other Racial/Ethnic categories for each of the three years $(+/-$ $1 \%$ ). More than half of the students at these schools were eligible for free or reduced price lunch (FRPL) although we are unsure if the respondents reflected the populations' income levels as we were not privy to student level FRPL datasets due to district policy and federal privacy regulations.

Table 1

\begin{tabular}{|c|c|c|c|}
\hline & \multicolumn{3}{|c|}{ Survey Year } \\
\hline & 2005 & 2006 & 2007 \\
\hline Total Surveys & 2819 & 3645 & 4117 \\
\hline \multicolumn{4}{|l|}{ Sex } \\
\hline Male & 1388 (49.24\%) & $1802(49.44 \%)$ & 2027 (49.23\%) \\
\hline Female & $1431(50.76 \%)$ & $1843(50.56 \%)$ & $2090(50.77 \%)$ \\
\hline \multicolumn{4}{|l|}{ Grade Level } \\
\hline 09 & $1036(36.75 \%)$ & $1216(33.36 \%)$ & 1358 (32.99\%) \\
\hline 10 & $1043(37.00 \%)$ & $1057(29.00 \%)$ & $1162(28.22 \%)$ \\
\hline 11 & $740(26.25 \%)$ & $841(23.07 \%)$ & $941(22.86 \%)$ \\
\hline 12 & $\mathrm{~N} / \mathrm{A}$ & $531(14.57 \%)$ & $656(15.93 \%)$ \\
\hline \multicolumn{4}{|l|}{ Race/Ethnicity } \\
\hline African American & $516(18.30 \%)$ & $672(18.44 \%)$ & 760 (18.46\%) \\
\hline Latino & $1531(54.31 \%)$ & $1986(54.49 \%)$ & $2282(55.43 \%)$ \\
\hline White & $353(12.52 \%)$ & $450(12.35 \%)$ & $486(11.80 \%)$ \\
\hline All Others & $419(14.86 \%)$ & $537(14.73 \%)$ & 589 (14.31\%) \\
\hline
\end{tabular}

\section{Student attitude measures}

Students' attitudes about the level of personalization felt at school and the utility of their advisory periods were assessed as part of a larger survey on school attitudes. Survey responses were constructed so that higher ratings of personalization indicated stronger feelings of connection with adults at their schools and an increasing sense that they were known and supported as individuals. Similarly, higher ratings on the advisory questions indicated increasing agreement that students found the advisory period valuable and believed that it was a useful adjunct to assist with current coursework and to help them navigate both academic and personal issues. Students responded to each survey item using a 6-point Likert scale; a response of " 1 " represented strong disagreement and " 6 " strong agreement to a statement. Because there were six response choices, the middle responses of " 3 " or " 4 " forced students to express either mild agreement or disagreement to each item.

The final data sets were subjected to a factor analysis to test whether or not the expected interrelationships existed between survey items -- to provide empirical support for our theoretic constructs. Although we had strong a priori ideas about the constructs we wanted to measure, and the questions that would allow us to address them, we wanted to make sure that the data supported these constructs. As such, we conducted a factor analysis to determine which questions "clumped together" best. We then used these results to identify the best combination of survey items for data reduction. Results of these analyses verified that the questions relating to personalization and the advisory period did indeed measure separate constructs that were internally cohesive. Table 2 contains the questions used to construct the scales and Table 3 provides information on the factor loading of each survey item. Survey items contained in the two factors did not cross-load; loading 
was consistent across administration years, and all items loaded "highly" or "moderately" into their respective scales (Hair, Anderson, Tatham \& Black, 1998; Raubenheimer, 2004). Composite survey variables were then created for each student by averaging a student's responses to the items contributing to each construct. Missing data for even one of the survey questions contributing to a factor/construct resulted in a missing value for that construct; an interpolation to adjust for missing data was not performed.

Table 2

Survey Items Loading into Personalization and Advisory Scales

\begin{tabular}{|c|c|c|}
\hline Scale & $\begin{array}{l}\text { Survey } \\
\text { Item }\end{array}$ & Survey Question \\
\hline \multirow{5}{*}{ Personalization } & 10 & There is at least one adult at my Small School whom I feel I can trust? \\
\hline & 12 & When I have a problem with school or a personal problem, there is at least one adult \\
\hline & 13 & at my Small School with whom I can talk to about by problem? \\
\hline & & \\
\hline & 15 & things to me frequently?* \\
\hline \multirow{4}{*}{ Advisory } & 23 & The advisory class at my Small School has made it easier to keep up in my classes? \\
\hline & 24 & My advisory teacher is someone I could go to for help? \\
\hline & 25 & $\begin{array}{l}\text { The advisory class at my Small School teaches me important lessons that I could use } \\
\text { later in life? }\end{array}$ \\
\hline & 26 & $\begin{array}{l}\text { I have learned a lot about myself and other students through my Small School's } \\
\text { advisory class? }\end{array}$ \\
\hline
\end{tabular}

*The word 'frequently' was bolded in the survey administered to students to emphasize that occasional comments by adults were not the object of the question.

Table 3

Factor Loading by Survey Item and Year

\begin{tabular}{|c|c|c|c|c|}
\hline \multirow{2}{*}{ Construct } & \multirow{2}{*}{ Survey Item } & \multicolumn{3}{|c|}{ Administration Year } \\
\hline & & 2005 & 2006 & 2007 \\
\hline \multirow{4}{*}{ Personalization } & 10 & .66 & .70 & .71 \\
\hline & 12 & .67 & .55 & .65 \\
\hline & 13 & .56 & .68 & .43 \\
\hline & 15 & .57 & .54 & .50 \\
\hline \multirow{4}{*}{ Advisory } & 23 & .70 & .72 & .63 \\
\hline & 24 & .64 & .68 & .59 \\
\hline & 25 & .78 & .81 & .78 \\
\hline & 26 & .73 & .70 & .71 \\
\hline
\end{tabular}

\section{Academic outcomes}

We were interested in the possibility that students' sense of personalization regarding their schools might predict their academic outcomes. We selected two outcomes, both for reasons of availability and consistency. Weighted grade point average (WGPA) was selected because it could be calculated for every student, because we believed it to be most directly influenced by student attitudes, and because it reflects students' understanding of course work taken. We were interested in the ways that students' perceptions of their schools related to their current academic achievement; therefore, we used only single-year WGPAs and not cumulative WGPAs in the analyses presented. 
We also considered the possibility that students' perceptions of personalization might relate to their performance on standardized tests. In California, only the English Language Arts (ELA scaled scores) subtest of the California Standards Test (CST) is required of all students in grades 9-11. The ELA was selected for this reason; while other tests are administered, those tests are tied to the specific coursework attempted and, therefore, are not universally administered. For example, a $9^{\text {th }}$ grade student in California, depending on the course taken, could be tested using one of 6 different mathematics tests; Algebra I, Algebra II and Geometry being the largest in terms of tests taken.

We did not want to make an assumption that the concept and execution of the advisory period was monolithic, so principals at the small schools were asked to complete a survey describing the specific aspects of advisory at their school. We collected information on duration, amount of structure, perceived importance and method of assignment. Across the schools, there were differences in time, structure and perceived importance. All students were assigned by grade level. We used this information as covariates in initial modeling to determine if, for example, advisory duration moderated the relationship between academic indicators and student perceptions of advisory. No statistically significant differences emerged with the addition of this information.

\section{Results}

For each grade in each survey year, relationships between student sex, personalization, advisory and measures of academic achievement were explored using hierarchical regression models (PROC Mixed in SAS) (Raudenbush \& Bryk, 1986; Singer, 1998). The hierarchical aspect was necessary because students were nested within schools. In fact, in all models tested, students within the same school were more alike than were students across schools, indicating that a hierarchical approach was both necessary and appropriate. Tables 4 and 5 (see Annex I) list the variance estimates corresponding to the random effect of school as well as an estimate of the variability across students once we controlled for the effect of school.

A clear and consistent pattern emerged from the set of analyses. Overall, student attitudes about personalization and advisory were significantly related to academic outcomes; higher levels of perceived personalization corresponded to higher WGPAs and ELA scores, and the reverse emerged for student opinions about the advisory period. Counter to our original predictions, stronger positive feelings about the efficacy of the advisory period corresponded to lower WGPAs and ELA scores.

Examining subgroups

To help understand why the overall findings played out as they did, we decided to examine if these findings held up within specific subgroups. Literature on personalization shows that many times youth perceive effective personalization as fair relationships with teachers and other school adults, varied instructional practices that address the range of ways students are engaged in classroom learning, a sense of belonging in the school, and a respectful and safe school climate, for example (Shultz \& Cook-Sather, 2001; Wilson \& Corbett, 2001; Yonezawa \& Jones, 2007). More importantly, this body of work tells us that youth across demographic subgroups often report similar versions of what successful personalization looks like in schools and classrooms (Wilson \& Corbett, 2001). Young people across sex, secondary grade levels/age, race and class categories and in suburban and urban educational environments view effective personalization similarly. Yet, what differentiates youth across demographic variables is the relationship between personalization and academic outcomes, with less advantaged groups continuing to struggle despite their similar desire for more personalized relationships. We wanted to examine in the analysis that follows if particular subgroups' academic outcomes were related to their feelings about advisory and personalization. 


\section{Looking at WGPA outcomes by subgroups: Grade level and sex}

Of the 11 groups (grade level by survey year) we analyzed, personalization was significantly related to WGPA in all but one. More specifically, higher personalization scores were predictive of higher WGPAs (and vice-versa) and an increase of one point on the 6-point scale was associated with WGPA increases ranging from 0.08 to $0.23 \mathrm{WGPA}$ points (Table 4). The only group where this relationship was not observed was in the $9^{\text {th }}$ graders from 2005 , who were entering high school in the first year of small school operation.

There were some differences between boys and girls, as a statistically significant interaction between sex and personalization was observed for two of the 2007 subgroups; the $9^{\text {th }}$ and $11^{\text {th }}$ graders. For the $11^{\text {th }}$ graders both girls and boys had a positive relationship between increased feelings of personalization and WGPAs, the difference being that the relationship was stronger for girls. For $9^{\text {th }}$ grade students, only males had a positive relationship between personalization and WGPA; the relationship for females was not statistically significant.

Advisory was significantly related to WGPA for 6 of the 11 groups analyzed. In all of these analyses, the direction of the relationship the same; more positive feelings about the advisory period were associated with lower WGPAs, and an increase of one point on the 6-point advisory scale was associated with decreases ranging from 0.07 to 0.11 WGPA points. There was only one significant interaction between sex and advisory, the $11^{\text {th }}$ graders in the 2005 survey administration. For females, higher ratings of advisory were associated with lower WGPAs $(\beta=-0.13, p<.001)$, while for males the opposite was true and positive feelings about advisory were associated with higher WGPAs $(\beta=0.09, p<.05)$.

Looking at WGPA outcomes by race and ethnicity subgroups

We conducted separate analyses for the two largest non-white racial and ethnic groups: Latinos and African Americans. For Latinos, more positive feelings about personalization were related to higher WGPAs -- the same relationship found in the overall analyses. But for Latino students, increasingly favorable opinions about the advisory were not related to WGPA in a statistically significant manner (with the exception of $11^{\text {th }}$ grade females in 2005). Knowing Latino students' views about advisory period was not predictive of how they were doing academically.

African American student opinions on the relationship between personalization and achievement were different from the overall analyses and findings. As African American students felt more positively about personalization their WGPAs increased significantly for only for the $11^{\text {th }}$ graders in 2006. The remaining analyses were not statistically significant. A similar pattern of results emerged for advisory, only one group of African American students had a significant relationship between advisory and WGPA, and that relationship was both related to sex and directional. In 2005, $11^{\text {th }}$ grade African American females' WGPAs decreased as their positive feelings about advisory increased $(\beta=-0.29, p<.01)$, the reverse was true for males $(\beta=0.20, p<.05)$. What this tells us is that, overall, knowing how African American students felt about personalization and advisory did not inform us about their academic performance as measured by WGPA.

ELA score outcomes by sex

Table 5.0 shows the relationships between sex, personalization, advisory and ELA scores. Of the 9 analyses (grades $9,10 \& 11$ for 3 survey years), personalization was significantly related to ELA scores in 7 of the 9 , and the consistent finding was that increased feelings of personalization were associated with higher ELA scores. An increase of one point on the 6-point scale personalization scale was associated with ELA increases ranging from 4 to 8 points. In 8 of the 9 analyses, more positive feelings about the advisory period were associated with lower ELA scores and an increase of one point on the advisory scale was associated with decreases in ELA scores ranging from 4.8 to 7.9 points. 
There were three significant interactions with sex. The first two were for students in grade 11 (2005) where there were statistically significant interactions for both personalization and advisory. Both males $(\beta=6.27, p<.05)$ and females $(\beta=13.23, p<.001)$ had positive relationships between personalization and ELA scores, and only females' had a significant relationship between advisory and ELA scores $(\beta=-7.66, p<.01)$; that relationship was negative and consistent with the main findings. The third interaction was for males in the $20079^{\text {th }}$ grade who had a positive relationship between personalization and ELA scores $(\beta=7.90, p<.001)$, while for girls there was no significant relationship.

Looking at ELA score outcomes by race and ethnicity

The analyses for African American and Latino students were also performed with ELA scores as the outcome measure. For Latino students, there was a fairly consistent pattern (5 of 9 analyses) where the same overall negative relationship between advisory and ELA scores held true, but in only one analysis $\left(9^{\text {th }}\right.$ grade, 2007) was the relationship between personalization and ELA scores statistically significant. For African American students 4 of 9 analyses showed a significant and negative relationship between advisory and ELA scores, with more positive feelings about advisory associated with lower ELA scores. While not as strong, this pattern mirrors that found in the overall analyses. However, for African American students, personalization and ELA scores did not have directionally consistent and/or statistically significant results and no trend emerged.

\section{Discussion}

Our study found that across grade levels and survey years an overall positive relationship exists between student perceptions of personalization and the two academic outcomes included in the analyses: WGPA and ELA scale scores. Simply stated, the more that students, felt personalization at their schools, the better students did academically. Moreover, we discovered an inverse relationship existed between students' perceptions of advisory programs and student academic outcomes. The more students, in general, reported satisfaction with advisory, the worse they performed academically.

Our findings lend some credibility to the purported academic effects of small schooling on students. We did not, for this report, examine the student survey self-report or academic data of student cohorts prior to entering the small schools in 2004 nor did we include a comparison group from traditional high schools. Nonetheless, our analyses do show a steady increase (in spring 2005, 2006, and 2007) in students' sense of personalization over time, for all subgroups, and a corresponding rise in academic achievement. In this way, we also contribute to a larger theoretical argument that modifying school structural arrangements may be helpful to reshaping cultural arrangements such as relationships within organizations.

But, most importantly, our results help educators, policy makers, and social scientists link personalization efforts at schools and academic achievement -- one not reliant on academic selfreport data. In this way, they lend credible quantitative support for the ideas espoused by other researchers who have argued that social-emotional relationships between teachers and students matter, but who have not yet uncovered quantitative research evidence linking personalization to measures of academic outcomes (Klem \& Connell, 2004; Hallinan, 2008).

For example, Wallach and her colleagues (2006) recently completed a study with student and teacher surveys and focus group, which examined personalization efforts in seven schools in Washington. The researchers found that students reported increased academic expectations of themselves and increased personal accountability between students and teachers as self-reported 
levels of personalization increased (Wallach, et al., 2006). Our study helps bolster their findings by linking increases in personalization to increases in WGPA and standardized test scores.

The implications for our findings in an era of decreasing state funding and heightened academic press underscore the importance schools and educators must place on efforts to personalize education and the social-emotional and academic benefits they can reap by doing so. Creating caring schools with adults attentive to students' needs appears to have value when the pay out is academic success both in school (WGPA) and in standardized test measures (ELA).

Nonetheless, while the positive relationship between personalization and academic achievement appears clear from our study, the role of advisory programs specifically in supporting personalization remains murky. The advisory programs we studied did not enjoy the same clear-cut, positive relationship with student achievement as personalization efforts more generally did. This is mainly evidenced by the fact that, in our study, ELA scores and, to a lesser extent, WGPAs tended to decrease the more that students felt that the advisory period was a meaningful addition to the school curriculum.

We provide a tentative interpretation of students' positive perception of personalization and their negative relationship with advisory. The simplest explanation is that students who needed advisory most (i.e., had the lowest grades, etc.) were the ones who valued advisory most, and vice versa, and the worse they performed, the more they valued advisory. Meanwhile, students who felt good about their position in school and their relationships with teachers tended to perform better academically.

An alternative explanation might be that students are distinguishing between the lived experiences of personalization versus the more bureaucratic, instrumental quality of advisory programs. They may acknowledge the human dynamics of particular teacher-student encounters within the overall notion of personalization, while they reject the more static institutionalized form of advisory as just another course in their academic schedule. That is, these students might be reminding us of Noddings's (1992) insights: Caring matters, more so when it appears in informal, improvised and, therefore, more authentic, encounters between teachers and students than when it appears in the formal structures of a course designated for that purpose. It may be for this reason that we see positive relationships between academic outcomes and personalization and negative relationships for the advisory period. Our findings lend credibility to Galassi and his colleagues' (1997) findings that more natural alternatives to structurally and culturally cumbersome advisory programs might be more successful. As McLaughlin (1987) said: Policy implementation is driven significantly by the belief systems, skills, and motivations of policy implementers -- "you can't mandate what matters."

A third explanation is that the advisory programs we studied in Avalon were either poorly or unevenly implemented. Because we conducted a one-time retrospective principal survey about their advisory programs in 2007 , we were unable to trace year-to-year programmatic changes with confidence. Moreover, we did not collect evidence through observation or teacher survey about the design and implementation of advisory programs as well as teacher training and teacher confidence regarding advisory. This is a shortcoming of our study and one that needs to be remedied in future work.

If, however, Avalon's advisory program was poorly implemented it would seem logical that the teachers and students' roles and relationship may not have been fundamentally altered to enough of a degree to create a positive effect in relationship to academic outcomes. But what might constitute, given our findings, a poorly constructed advisory program? Even if the advisory programs in Avalon did manage to craft significantly positive new teacher-student relationships, the often loose-coupling of advisory and core academic course relationships between teachers and students might be enough to weaken any academic impact. For example, even if advisory programs 
altered students' relationships with teachers, these relationships may not translate into new classroom behaviors if students do not take core courses from their advisory teachers. Yet few advisory programs, not just those in the district we studied, are constructed to ensure overlap between students' advisory teachers and core academic teachers. This is partly because of resources and scheduling. There are often not enough teachers to run an advisory program unless elective and other school faculty and staff are advisors as well.

A final alternative explanation worth mentioning is that advisory may act largely on secondary student behaviors such as attendance or conduct rather than as a direct mediator of academic performance. If true, then the success of the advisory period would be to retain more students who both appreciate the advisory period and are likely to have poor academic records; the success of the advisory period would, in part, drive the observed inverse relationship.

Our efforts to understand the overall relationships between students' perceptions of personalization and advisory on the one hand and academic achievement on the other hand were complicated further by our subgroup analyses by race and sex. In our additional examination by race and sex we learned that students perceive efforts by adults to connect with them--whether through less structured personalization efforts or more structured advisory programs--in different ways across various sub groups. For example, with Latino students, personalization, but not advisory, seemed to have an important and positive relationship with academic achievement. For African American students, however, neither personalization nor advisory seemed to have a significant relationship with their academic performance. The results for sex were limited, with a few scattered instances where the relationship between personalization, advisory, and the academic outcomes were moderated by gender. While we cannot determine why this is the case within the confines of this paper, suffice it to say that race and sex matter in that they vary in complex ways and moderate the degree to which efforts by adults appear to be effective. They certainly warrant further study. Moreover, grade level of students also must be taken into account as the social-emotional and cognitive needs of students are shaped by their physical and mental development.

The subgroup analyses do, however, cause us to speculate about the importance of peer groups in examining personalization efforts in schools. Given students' tendencies to formalize peer groups within racial and sex boundaries (particularly at earlier grades), it seems important that future work in this area might attend to the impact these groups have on students within both formal personalization structures such as advisory and informal, extracurricular avenues to personalization. We were unable to study peer effects in this research project; however, we concede of the need to do so in the future.

What are the alternatives to structured efforts such as advisory to improve students' connections to schools and adults? Ultimately, personalization approaches must move efforts into the core of schooling. Students spend far more time with their academic teachers in core courses than with counselors, advisory teachers, and administrators. Schools able to integrate strategies of caring into their daily work and overall school climate, as opposed to annexing it within an advisory period, may be more successful.

Strategies for integrating personalization more completely into schools may require more creative approaches by policy makers and educators charged with supporting school personnel and student achievement. For example, policies that support the tenuous relationships teachers manage to build with students over time -- looping (retaining the same students with the same teacher over multiple years), retention incentives for teachers, particularly in low-income and high minority schools, multi-age grouping strategies, and team teaching arrangements may provide the link to personalization without isolating the effort in adjunct programs such as advisory. These and other more creative approaches could help create tighter-knit student-teacher relationships develop more naturally over time. 


\section{Policy Implications}

While the data presented are relational and not causal, they suggest that policies are needed to encourage and strengthen personalization across schools without an over-reliance on advisory programs as the single means of achieving that goal. Such limited structural changes are likely to be insufficient to increase student learning, engagement and achievement. The cultural or social component of schooling must be explicitly addressed and woven throughout the school-community, rather than isolated within a single course or area of the school.

Formal and informal opportunities to strengthen adult-student relationships matter and policies aimed at creating positive environments or socio-cultural climates of caring and respect within a range of both formal and informal settings are needed. In other words, policies are needed that encourage adults to focus on the content and substance of their interactions with students. Structural creativity within schools is needed to allow for the evolution of new ways for teachers to authentically connect with students.

Toward this end, policies are needed which advocate that teachers work on personalization content in a professional learning community and, in particular, provide adults with on-going school site support for developing increasingly tighter-knit relationship with students. In such professional learning communities, teachers (and counselors) could gain exposure to and share ideas about curriculum, activities to use in formal opportunities (advisory, core classrooms) and about informal ways to build strong and positive relationships with students.

\section{References}

Alexander, W.M. \& Williams, E.L. (1965). Schools for the middle years. Educational Leadership, 23, 217-223.

American Psychological Association. (2001). Publication Manual of the American Psychological Association (5th ed.). (2001). Washington, DC: Author.

Blum, R.W., and H. P. Libbey, eds. (2004). School connectedness: Strengthening health and education outcomes for teenagers. Special issue, Journal of School Health, 74(7), 229-99

Blum, R.W, McNeely, C.A., \& Rinehart, P.M. (2002). Improving the odds: The untapped power of schools to improve the health of teens. Minneapolis: University of Minnesota, Center for Adolescent Health and Development.

Bryk, A.S. \& Driscoll, M.E. (1988). The school as community: Theoretical foundations, contextual influences, and consequences for students and teachers. Madison, WI: Center on Effective Secondary Schools, University of Wisconsin.

Epstein, J. L. \& MacIver, D.J. (1990). Education in the middle grades: Overview of national practices and trends. Columbus, OH: National Middle School Association.

Fredricks, J.A., Blumenfeld, P.C. \& Paris, A.H. (2004). School engagement: Potential of the concept, state of the evidence. Review of Educational Research, 74(1), 59-109.

Galassi, J.P., Gulledge, SA. \& Cox, N.D. (1997). Middle school advisories: Retrospect and prospect. Review of Educational Research, 67(3), 301-338.

Gewertz, C. (2007). An advisory advantage. Education Week, 26(26), 22-25.

Hair, J.F., Anderson, R. E.,Tatham, R. L. \& Black, W. C. (1998). Multivariate data analysis with readings, 5 th ed. Englewood Cliffs, NJ: Prentice-Hall.

Hallinan, M.T. (2008). Teacher influences on students' attachment to school. Sociology of Education, 81(July), 271-283.

Klem A., \& Connell, J. (2004). Relationships matter: Linking teacher support to student engagement and achievement. Philadelphia: Institute for Research and Reform in Education 
Lee, V.E., Bryk, A.S., Smith. (1993a). The organization of effective high schools. In L. Darling Hammond (Ed.) Review of Research in Education, 19, Washington, DC: American Educational Research Association, pp. 171-267.

Lee, V.E., Bryk, A.S., \& Smith, J. (1993b). The effects of high school organization on teachers and students. Review of Research in Education, 19, 171-268.

Lee, V. E. \& Smith, J. (1993). Effects of school restructuring on the achievement and engagement of middle-grade students. Sociology of Education, 66, 164-187).

Lee, V. E. \& Smith, J. (1995). Effects of high school restructuring and size on early gains in achievement and engagement. Sociology of Education, 68, 241-270.

Lee, V. E. \& Smith, J. (1996). Collective responsibility for learning and its effects on gains in achievement for early secondary school students. American Journal of Education, 104(2), 103147.

Lee, V. E. \& Smith, J. (1997). High school size: Which works best and for whom? Educational Evaluation and Policy Analysis, 19,(3), 205-227.

Lee, V.E., Smith, J. \& Croninger, R.G. (1997). How high school organization influences the equitable distribution of learning in mathematics and science. Sociology of Education, 70(2), 129-152.

Makkonen, R. (2004). Advisory program research and evaluation. CES National Web. Retrieved June 05, 2009 from, http://www.essentialschools.org/cs/resources/view/ces_res/345

McLaughlin, M. (1987). Learning from experience: Lessons from policy implementation. Educational Evaluation and Policy Analysis, 9(2), 171-178.

McNeely, C.A. \& C. Falci (2004) School Connectedness and the Transition Into and Out of Health Risk Behavior among Adolescents: A Comparison of Social Belonging and Teacher Support. Journal of School Health 74(7), 284-292.

McNeely, C.A., J.M. Nonnemaker and R.W. Blum (2002) Promoting Student Connectedness to School: Evidence from the National Longitudinal Study of Adolescent Health. Journal of School Health 72(4):138-146.

Mosteller, F., Sachs, J., \& Light, R. (1996). Sustained inquiry in education: lessons from skill grouping and class size. Harvard Educational Review, 66, 797-828.

Mosteller, F. (1995). The Tennessee study of class size in the early school grades. The Future of Children, 5, 113-127.

Noddings, N. (1992). The challenge to care in schools: An alternative approach to education. Advances in Contemporary Educational Thought series, vol. 8. New York: Teachers College Press.

Raubenheimer, J. E. (2004). An item selection procedure to maximize scale reliability and validity. South African Journal of Industrial Psychology, 30 (4), 59-64.

Raudenbush, S., \& Bryk, A. S. (1986). A hierarchical model for studying school effects. Sociology of Education, 59(1), 1-17.

School Redesign Network (2000). Redesigning schools: 10 features of effective design. Palo Alto, CA: Stanford Redesign Network.

Shultz, J. \& Cook-Sather, A. (2001). In our own words: Students' perspectives on school. Lanham, Maryland: Rowman \& Littlefield Publishers.

Singer, J. D. (1998). Using SAS PROC MIXED to fit multilevel models, hierarchical models, and individual growth models. Journal of Educational and Behavioral Statistics, 24(4), 323-354.

Sizer, T.R. (1984). Horace's compromise: The dilemma of the American high school. Boston: Houghton Mifflin.

Steinberg, A. \& Allen, L. (2002). From large to small: Strategies for personalizing the high school. Boston: Jobs for the Future.

Stiefel, L., Berne, R., Iatarola, P. \& Fruchter, N. (2000). "High School Size: The Effects on 
Budgets and Performance in New York City," Educational Evaluation and Policy Analysis, 22 (1):27-39.

Wallach, C., Ramsey, B. Copland, M. \& Lowry, L.K. (2006). Student voice: Tapping the potential of relationships, relevance, and rigor. Seattle, WA: Small Schools Project.

Wilson, B. \& Corbett, H.D. (2001). Listening to urban kids: School reform and the teachers they want. New York: State University of New York Press.

Yonezawa, S. \& Jones, M. (2007). Using students' experiences in the classroom to evaluate and inform secondary school reform. In A. Cook-Sather \& D. Thiessen (Eds.), International bandbook of student experience in elementary and secondary school (pp. 691-710). The Netherlands: Springer. 


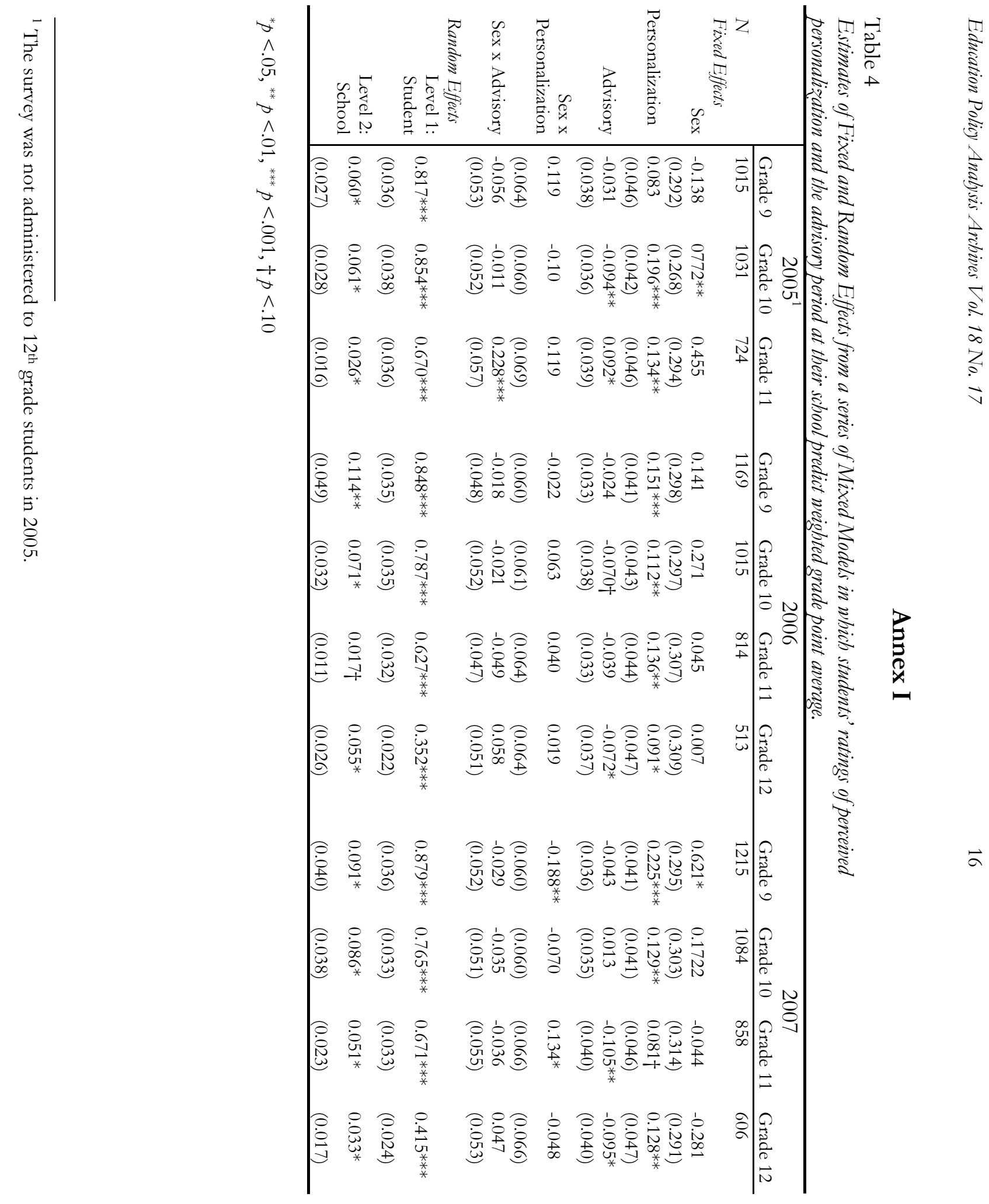




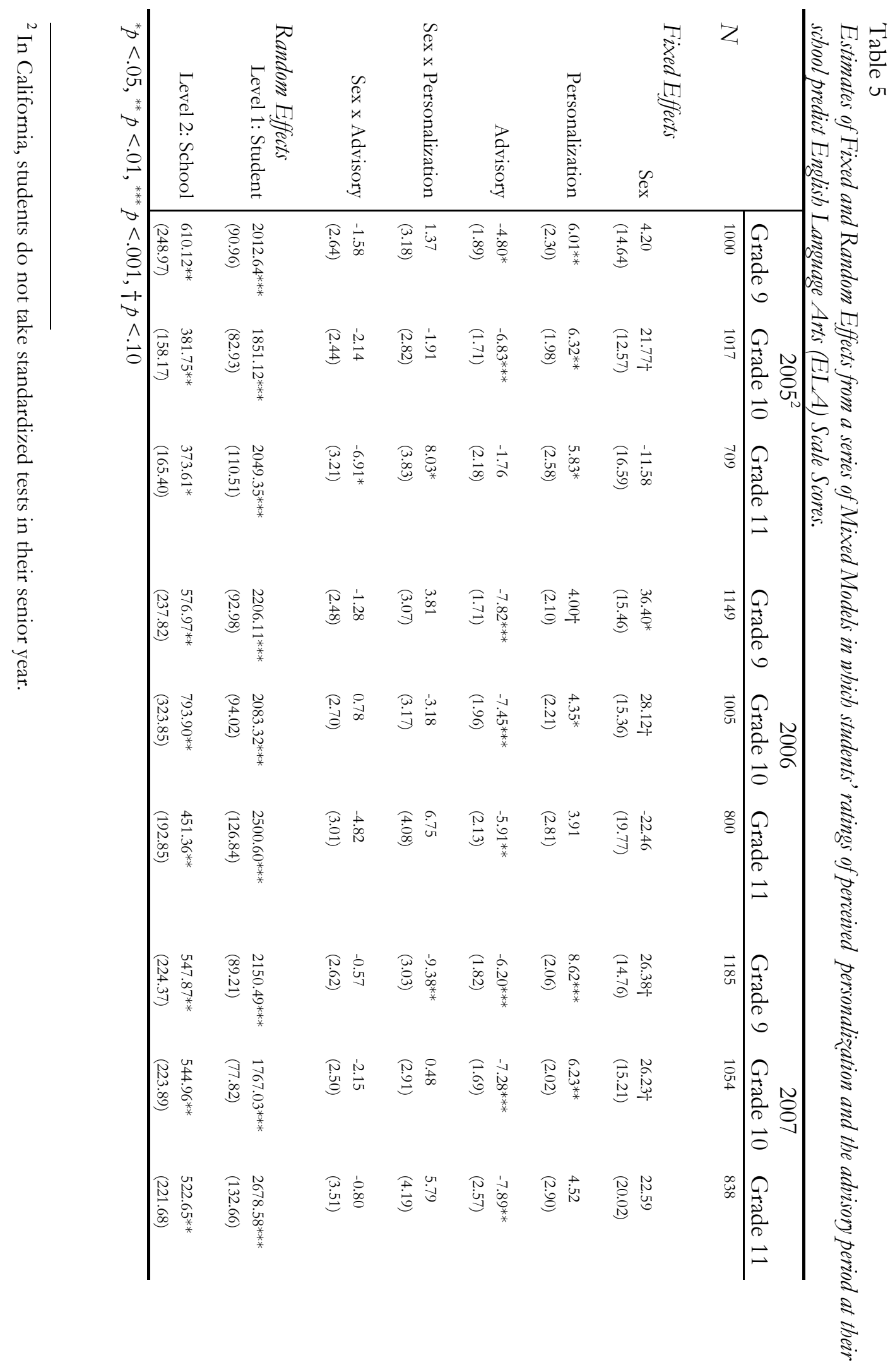

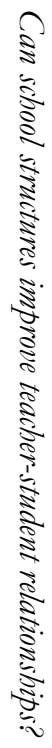




\begin{abstract}
About the Authors
McClure, Yonezawa and Jones are at the Center for Research on Educational Equity, Assessment, and Teaching Excellence (CREATE) at the University of California, San Diego.

Correspondence concerning this article should be addressed to Larry McClure, Center for Research on Educational Equity, Assessment, and Teaching Excellence (CREATE), University of California, San Diego, Mail Code 0036, 9500 Gilman Drive, La Jolla, CA 92093. Email: 1mcclure@,ucsd.edu
\end{abstract}

This work was funded, in part, by a grant from the California Education Supports Project, sponsored by The California Endowment, The James Irvine Foundation and the Hewlett Foundation: a joint project of WestEd and the Philip R. Lee Institute for Health Policy, UC San Francisco. The authors wish to thank these agencies and Greg Austin for their support.

\title{
education policy analysis archives
} work is attributed to the author(s) and Education Policy Analysis Archives, it is distributed for non-commercial purposes only, and no alteration or transformation is made in the work. More details of this Creative Commons license are available at http://creativecommons.org/licenses/by-nc-sa/3.0/. All other uses must be approved by the author(s) or EPAA. EPAA is published by the Mary Lou Fulton Institute and Graduate School of Education at Arizona State University Articles are indexed EBSCO Education Research Complete, Directory of Open Access Journals, ERIC, H.W. WILSON \& Co, QUALIS - A 2 (CAPES, Brazil), SCOPUS, SOCOLAR-China.

Please contribute commentaries at http://epaa.info/wordpress/ and send errata notes to Gustavo E. Fischman fischman@asu.edu
} 


\section{education policy analysis archives editorial board}

Editor Gustavo E. Fischman (Arizona State University)

Associate Editors: David R. Garcia \& Jeanne M. Powers (Arizona State University)

Jessica Allen University of Colorado, Boulder

Gary Anderson New York University

Michael W. Apple University of Wisconsin, Madison

Angela Arzubiaga Arizona State University

David C. Berliner Arizona State University

Robert Bickel Marshall University

Henry Braun Boston College

Eric Camburn University of Wisconsin, Madison

Wendy C. Chi* University of Colorado, Boulder

Casey Cobb University of Connecticut

Arnold Danzig Arizona State University

Antonia Darder University of Illinois, Urbana-

Champaign

Linda Darling-Hammond Stanford University

Chad d'Entremont Strategies for Children

John Diamond Harvard University

Tara Donahue Learning Point Associates

Sherman Dorn University of South Florida

Christopher Joseph Frey Bowling Green State University

Melissa Lynn Freeman* Adams State College

Amy Garrett Dikkers University of Minnesota

Gene V Glass Arizona State University

Ronald Glass University of California, Santa Cruz

Harvey Goldstein Bristol University

Jacob P. K. Gross Indiana University

Eric M. Haas WestEd

Kimberly Joy Howard* University of Southern

California

Aimee Howley Ohio University

Craig Howley Ohio University

Steve Klees University of Maryland

Jaekyung Lee SUNY Buffalo
Christopher Lubienski University of Illinois, Urbana-Champaign

Sarah Lubienski University of Illinois, Urbana-

Champaign

Samuel R. Lucas University of California, Berkeley

Maria Martinez-Coslo University of Texas, Arlington

William Mathis University of Colorado, Boulder

Tristan McCowan Institute of Education, London

Heinrich Mintrop University of California, Berkeley

Michele S. Moses University of Colorado, Boulder

Julianne Moss University of Melbourne

Sharon Nichols University of Texas, San Antonio

Noga O'Connor University of Iowa

João Paraskveva University of Massachusetts, Dartmouth

Laurence Parker University of Illinois, Urbana-

Champaign

Susan L. Robertson Bristol University

John Rogers University of California, Los Angeles

A. G. Rud Purdue University

Felicia C. Sanders The Pennsylvania State University

Janelle Scott University of California, Berkeley

Kimberly Scott Arizona State University

Dorothy Shipps Baruch College/CUNY

Maria Teresa Tatto Michigan State University

Larisa Warhol University of Connecticut

Cally Waite Social Science Research Council

John Weathers University of Colorado, Colorado Springs

Kevin Welner University of Colorado, Boulder

Ed Wiley University of Colorado, Boulder

Terrence G. Wiley Arizona State University

John Willinsky Stanford University

Kyo Yamashiro University of California, Los Angeles

* Members of the New Scholars Board 
archivos analíticos de políticas educativas

consejo editorial

Editor: Gustavo E. Fischman (Arizona State University)

Editores. Asociados Alejandro Canales (UNAM) y Jesús Romero Morante (Universidad de Cantabria)

Armando Alcántara Santuario Instituto de

Investigaciones sobre la Universidad y la Educación, UNAM México

Claudio Almonacid Universidad Metropolitana de

Ciencias de la Educación, Chile

Pilar Arnaiz Sánchez Universidad de Murcia, España

Xavier Besalú Costa Universitat de Girona, España Jose Joaquin Brunner Universidad Diego Portales, Chile

Damián Canales Sánchez Instituto Nacional para la Evaluación de la Educación, México

María Caridad García Universidad Católica del Norte, Chile

Raimundo Cuesta Fernández IES Fray Luis de León, España

Marco Antonio Delgado Fuentes Universidad

Iberoamericana, México

Inés Dussel FLACSO, Argentina

Rafael Feito Alonso Universidad Complutense de Madrid, España

Pedro Flores Crespo Universidad Iberoamericana, México

Verónica García Martínez Universidad Juárez

Autónoma de Tabasco, México

Francisco F. García Pérez Universidad de Sevilla, España

Edna Luna Serrano Universidad Autónoma de Baja California, México

Alma Maldonado Departamento de Investigaciones Educativas, Centro de Investigación y de Estudios Avanzados, México

Alejandro Márquez Jiménez Instituto de Investigaciones sobre la Universidad y la Educación, UNAM México

José Felipe Martínez Fernández University of California Los Angeles, USA
Fanni Muñoz Pontificia Universidad Católica de Perú

Imanol Ordorika Instituto de Investigaciones Economicas - UNAM, México

Maria Cristina Parra Sandoval Universidad de Zulia, Venezuela

Miguel A. Pereyra Universidad de Granada, España Monica Pini Universidad Nacional de San Martín, Argentina

Paula Razquin UNESCO, Francia

Ignacio Rivas Flores Universidad de Málaga, España

Daniel Schugurensky Universidad de TorontoOntario Institute of Studies in Education, Canadá

Orlando Pulido Chaves Universidad Pedagógica Nacional, Colombia

José Gregorio Rodríguez Universidad Nacional de Colombia

Miriam Rodríguez Vargas Universidad Autónoma de Tamaulipas, México

Mario Rueda Beltrán Instituto de Investigaciones sobre la Universidad y la Educación, UNAM México

José Luis San Fabián Maroto Universidad de Oviedo, España

Yengny Marisol Silva Laya Universidad Iberoamericana, México

Aida Terrón Bañuelos Universidad de Oviedo, España

Jurjo Torres Santomé Universidad de la Coruña, España

Antoni Verger Planells University of Amsterdam, Holanda

Mario Yapu Universidad Para la Investigación Estratégica, Bolivia 
arquivos analíticos de políticas educativas

conselho editorial

Editor: Gustavo E. Fischman (Arizona State University)

Editores Associados: Rosa Maria Bueno Fisher e Luis A. Gandin

(Universidade Federal do Rio Grande do Sul)

Dalila Andrade de Oliveira Universidade Federal de Minas Gerais, Brasil

Paulo Carrano Universidade Federal Fluminense, Brasil

Alicia Maria Catalano de Bonamino Pontificia

Universidade Católica-Rio, Brasil

Fabiana de Amorim Marcello Universidade

Luterana do Brasil, Canoas, Brasil

Alexandre Fernandez Vaz Universidade Federal de Santa Catarina, Brasil

Gaudêncio Frigotto Universidade do Estado do Rio de Janeiro, Brasil

Alfredo M Gomes Universidade Federal de

Pernambuco, Brasil

Petronilha Beatriz Gonçalves e Silva Universidade Federal de São Carlos, Brasil

Nadja Herman Pontificia Universidade Católica Rio Grande do Sul, Brasil

José Machado Pais Instituto de Ciências Sociais da Universidade de Lisboa, Portugal

Wenceslao Machado de Oliveira Jr. Universidade

Estadual de Campinas, Brasil
Jefferson Mainardes Universidade Estadual de Ponta Grossa, Brasil

Luciano Mendes de Faria Filho Universidade Federal de Minas Gerais, Brasil

Lia Raquel Moreira Oliveira Universidade do Minho, Portugal

Belmira Oliveira Bueno Universidade de São Paulo, Brasil

António Teodoro Universidade Lusófona, Portugal

Pia L. Wong California State University Sacramento, U.S.A

Sandra Regina Sales Universidade Federal Rural do Rio de Janeiro, Brasil

Elba Siqueira Sá Barreto_Fundação Carlos Chagas, Brasil

Manuela Terrasêca Universidade do Porto, Portugal

Robert Verhine Universidade Federal da Bahia, Brasil

Antônio A. S. Zuin Universidade Federal de São Carlos, Brasil 